\title{
Burrowing Rodents: Developing a Management Plan for Organic Agriculture in California
}

MARGARET G. LLOYD,

UC Cooperative Extension Small Farms Advisor in Yolo, Solano, and Sacramento counties

ROGER A. BALDWIN, UC Cooperative Extension Wildlife Specialist, Department of Wildlife, Fish, and Conservation Biology, UC Davis urrowing rodents can cause exten-

sive damage in organic production systems. The three most common species that cause damage are

- California ground squirrels (Otospermophilus spp.)

- pocket gophers (Thomomys spp.)

- meadow voles (Microtus spp.)

\section{IDENTIFICATION}

Body features, activity patterns, damage caused, and appearance of burrow entrances are useful in identifying burrowing rodents.

\section{California ground squirrels}

Ground squirrels are grayish-brown rodents (fig. 1) in the squirrel family that primarily live on or in the ground, although they occasionally climb trees to access fruit and nuts. They are active during the day, when they move around foraging for food. When alarmed, they give a loud chirp and often drop into burrows that

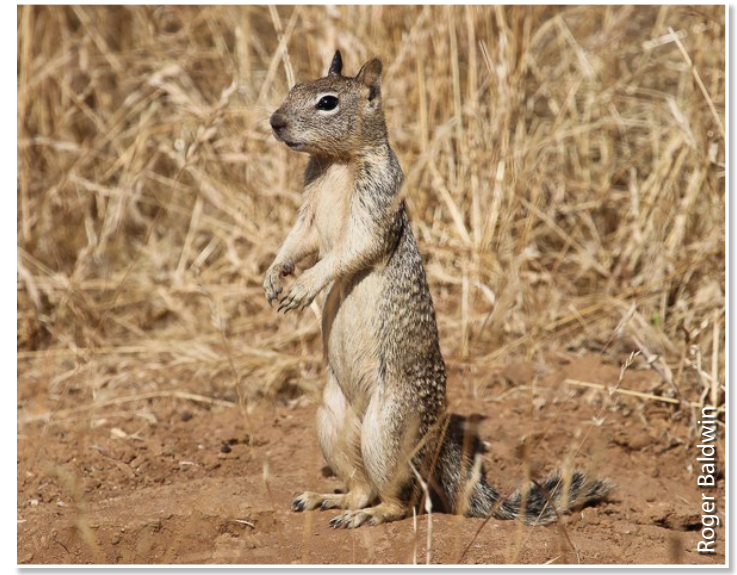

Figure 1. California ground squirrel. they have dug (and where they nest). Their burrow entrances remain open at the surface, often with multiple entrances within a small area. They readily coexist with people, creating burrows in and around buildings. They also create burrows next to trees (fig. 2) and along field edges, fencerows, and roadsides. Ground squirrels hibernate during the winter, but can remain active in areas with mild winters (Quinn et al. 2018).

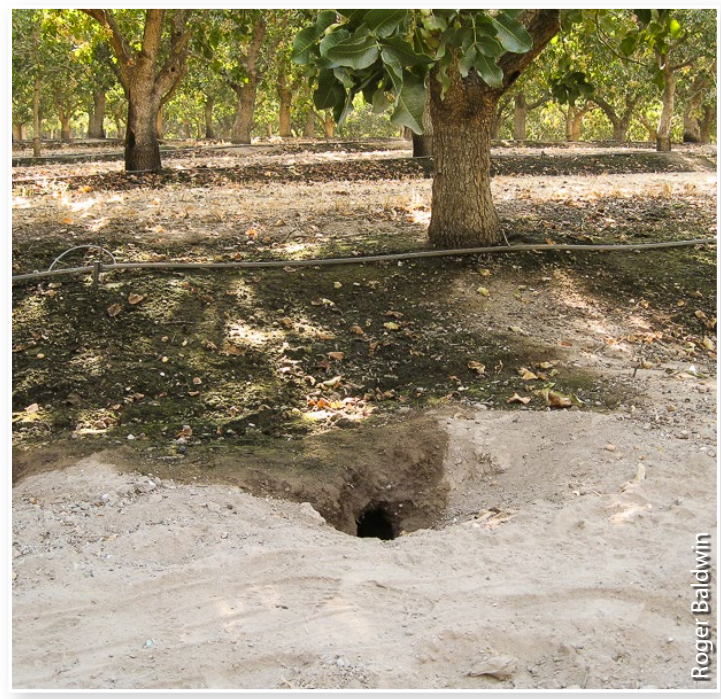

Figure 2. Ground squirrel burrow entrance.

Ground squirrels can severely reduce seedling stands when they feed on emerging plants. They can kill limbs and entire trees through girdling activities. They feed on fruit and nut crops, reducing yield. They also chew on irrigation lines, necessitating costly repairs, and their burrows can disrupt irrigation systems, damage crops, lead to erosion concerns, and pose a hazard to farm equipment and farmworkers. Ground squirrels sometimes travel 100 yards or more to feed on crops and frequently create burrows in perennial crops such as orchards. 


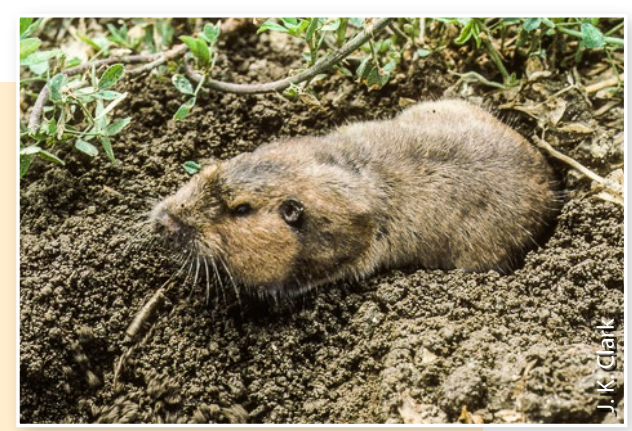

Figure 3. Pocket gopher.

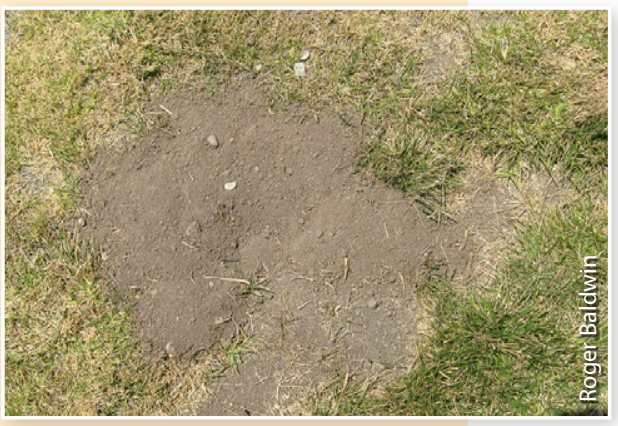

Figure 4. Crescent-shaped pocket gopher mound with plug found in lower middle of the mound.

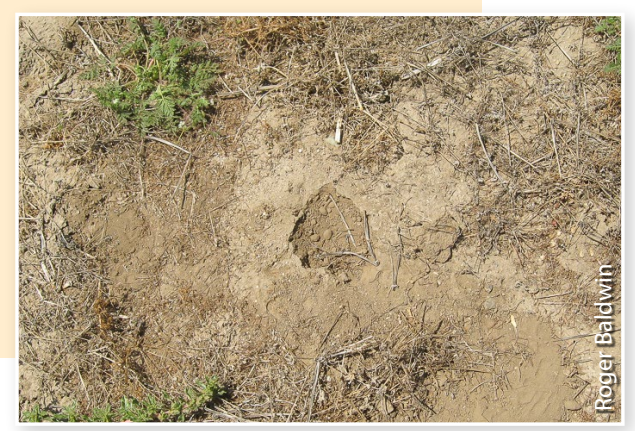

Figure 5. Pocket gopher feeder hole.

\section{Pocket gophers}

Pocket gophers are grayish-brown rodents, about 6 to 8 inches in length, that live almost entirely underground (fig. 3). They are best identified by the crescent-shaped mounds of dirt on top of the soil that they push up when constructing burrows (fig. 4). Pocket gophers also create feeder holes, which are small, plugged burrow entrances lacking an associated mound (fig. 5). Gophers feed on vegetation within a couple of inches around this feeder hole, and then plug the burrow entrance once feeding is complete. Typical pocket gopher damage occurs through feeding on taproots, which can weaken or kill plants, girdling of trees and vines below ground, and mound construction, which can kill seedling plants and encourage weed intrusion. Pocket gophers' burrow systems can channel water, potentially leading to severe soil erosion problems and interfering with irrigation water movement across a

field. Pocket gophers chew on and damage subsurface drip lines, and their mounds pose a hazard to farm equipment and farmworkers. Gophers can reproduce throughout the year on irrigated cropland, with peak breeding occurring in late winter through early spring. Gopher control is best conducted in late fall through early spring due to high levels of mounding activity at that time (Cox and Hunt 1992).

Moles (Scapanus spp.) are sometimes confused with pocket gophers because their mounds often look similar, though mole mounds are more rounded, like a volcano, instead of crescent-shaped (fig. 6). However, moles are insectivores, not rodents, and feed primarily on worms, grubs, and insects. They do not damage plants through feeding activities, though their mounds can cause the same concerns that gopher mounds cause. Because moles do not impact plants directly, they are not discussed further in this publication. For more information about moles and how to manage them, please see the UC Integrated Pest Management (IPM) Pest Note on moles, ipm.ucanr.edu/PMG/PESTNOTES/pn74115. html.

\section{Voles (meadow mice)}

Voles (meadow mice) are small, mouse-like rodents (fig. 7) that dig shallow burrows and leave well-worn trails between burrow openings in fields (figs. 8 and 9). Fresh fecal pellets and fresh-clipped grass can be used to identify active runways. Voles have dark, grayish-brown fur and are 4 to 6 inches in length. Their numbers are cyclical, with population outbreaks every 4 to 6 years. Voles can reproduce many times a year, but often have a peak breeding period in spring (Salmon and Gorenzel 2010). Damage caused by voles occurs primarily above ground and can include stem girdling and consumption of vegetation. Voles also

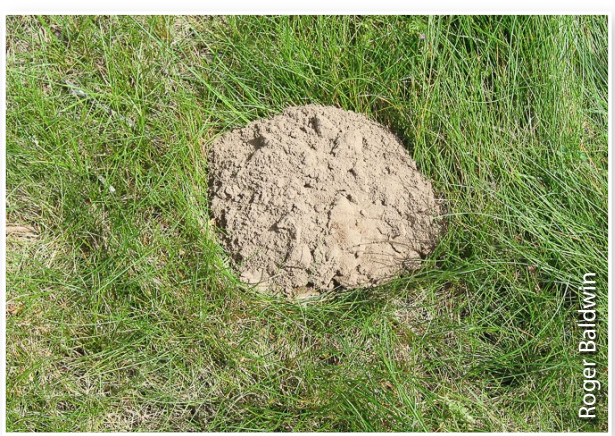

Figure 6. Mole mound.

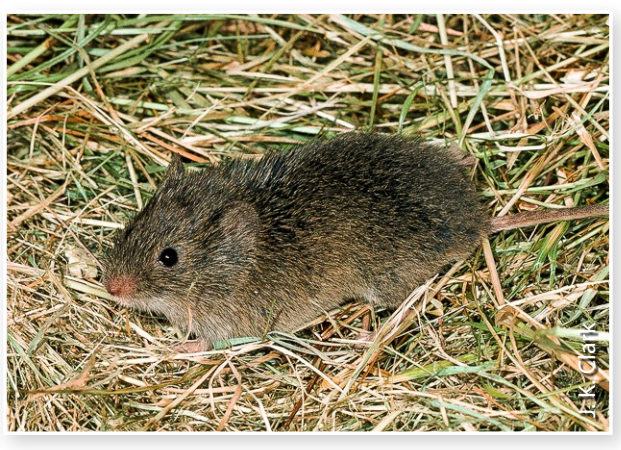

Figure 7. Meadow vole.

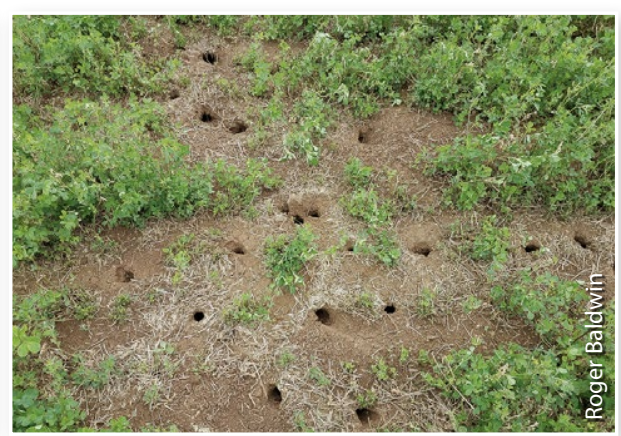

Figure 8. Meadow vole burrow entrances. 


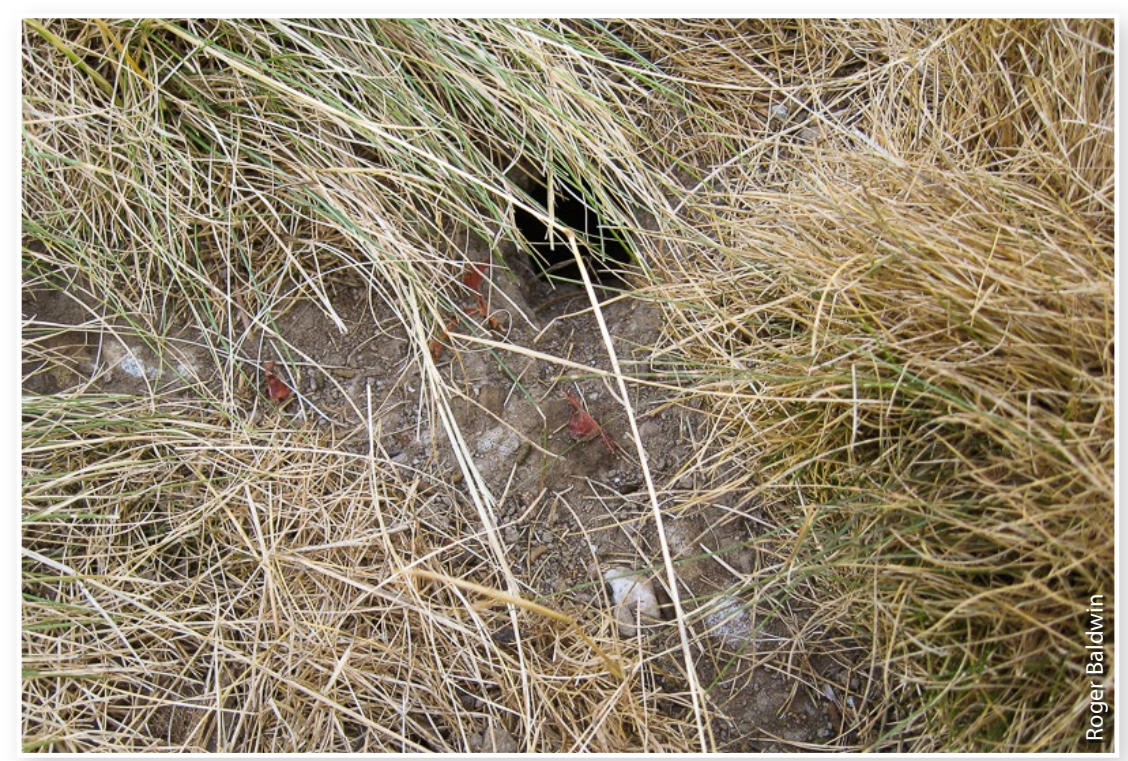

Figure 9. Meadow vole runway.

chew irrigation tubing, electrical cables, and pipes, damaging them.

Two main features can be used to differentiate between voles and gophers when no visual identification of the animal has been made. Voles leave open burrow entrances about 1 to 1.5 inches in diameter-whereas gopher burrow entrances are usually covered with a crescent-shaped mound. That said, plugs from gopher feeding holes will cave in once soil dries out, often leaving a number of open holes in a vineyard or orchard floor that can look similar to vole burrow entrances. In these situations, look for well-worn trails created by voles that link their burrow entrances (see fig. 9). Pocket gophers lack such trails because they predominantly move below ground. Differentiating between plant and irrigation damage caused by gophers and by voles is difficult, but in general, gopher damage occurs below ground and vole damage occurs from ground level to 6 inches above ground. Be aware that there can be exceptions to this rule, though.

\section{MANAGEMENT}

Strategies for control of burrowing rodents in organic systems include biocontrol, habitat modification, cultural practices, exclusion, trapping, and shooting (table 1). Although rodenticide baiting and burrow fumigation are regularly used for burrowing rodent control in conventional agricultural systems, Vitamin D3 is the only rodenticide certified for use within organic systems. Even then, it can only be used for roof rats (Rattus rattus), Norway rats (Rattus norvegicus), and house mice (Mus musculus), and only indoors or within 50 feet of a structure. If the grower has a split operation, and a conventional field is adjacent to an organic field, the grower can use conventional rodenticides in the conventional field. As a general rule, certifiers will require a 25 -foot buffer between conventionally approved products in a conventional field and the start of the certified organic field. Be sure to check with your certifier and continually monitor the Organic Materials Review Institute, omri.org, for approved rodenticides in organic production and specifications for buffer areas.

In the following sections, we will discuss how available tools can be implemented for management of ground squirrels, pocket gophers, and voles in organic production systems. We present these tools individually to facilitate discussion. That said, effective, sustainable rodent control generally relies on an IPM approach that incorporates multiple strategies. We will provide more details on how

Table 1. Organic management methods that can be used for burrowing rodents

" $X$ " indicates methods that are generally applicable and effective, while "?" indicates situations in which efficacy is unknown or varies depending on specific conditions. For cells without an "X" or "?", the specified control option is not effective and/or legal for the specified species or under organic certification.

\begin{tabular}{|l|l|l|l|l|l|l|l|l|} 
& Biocontrol & $\begin{array}{l}\text { Habitat } \\
\text { modification }\end{array}$ & $\begin{array}{l}\text { Cultural } \\
\text { practices }\end{array}$ & Baiting & $\begin{array}{l}\text { Burrow } \\
\text { fumigation }\end{array}$ & Trapping & Exclusion & Shooting \\
\hline Ground squirrel & & $\mathrm{X}$ & $\mathrm{X}$ & & $\mathrm{X}$ & $\mathrm{X}$ \\
\hline Pocket gopher & $?$ & $\mathrm{X}$ & $\mathrm{X}$ & & $\mathrm{X}$ & $?$ \\
\hline Vole & $?$ & $\mathrm{X}$ & $\mathrm{X}$ & & $?$ & $\mathrm{X}$ \\
\hline
\end{tabular}




\begin{tabular}{|l|l|l|l|}
\multicolumn{2}{l}{ Winter } & Spring Summer Autumn \\
\hline \multicolumn{2}{|l|}{ Major activity periods } & & \\
\hline Juveniles & & & \\
\hline Adults & & & \\
\hline Reproduction & & & \\
\hline
\end{tabular}

Major food source

\begin{tabular}{|l|l|l|l|}
\hline Green foliage & & \\
\hline Seeds & & & \\
\hline
\end{tabular}

Best time for control

Trapping

Figure 10. Major activity periods, food sources, and best time for control for California ground squirrels throughout the year.

to implement an IPM program at the end of this publication. However, keep in mind that there will not necessarily be any single best strategy for dealing with damage situations in a given field. A creative and adaptive approach is often needed to mitigate rodent damage in organic production systems.

\section{Understanding rodent life cycles}

The first issue to consider is the general life cycle of the rodent in question. Ground squirrels often hibernate in winter and estivate (undergo a period of inactivity) during the hottest parts of the summer (fig. 10). These periods are important to note because ground squirrel management must focus on the time frames when ground squirrels are active.

Furthermore, ground squirrels reproduce in later winter and early spring. Young are very dependent on their mothers until they emerge above ground and start to forage on their own. Therefore, removal efforts targeted during spring are often more effective and practical because, at that time of year, newborn ground squirrels are not yet part of the population that has to be controlled.

Pocket gophers are active year-round. However, they mound more during late fall through spring when soil moisture is highest. Gophers are easier to find and remove during that time frame because mounds are easier to spot and soils are more friable when moist. Also, although gophers can reproduce year-round, there is often a reproductive pulse in later winter and early spring. Removing gophers before that reproductive pulse will reduce the number of gophers that must be removed. For all these reasons, large-scale management efforts should focus on late fall through early spring to minimize control efforts and maximize efficacy.

Vole numbers tend to be lowest in early winter to midwinter. If vole removal efforts are possible, control may be most effective at that time. Though trapping is the only removal effort available, it has limited utility for a species as numerous as voles. As such, it is essential to take steps to minimize opportunities for vole damage in organic systems (for example, habitat modification and exclusion; details are provided in subsequent sections).

\section{Biocontrol using natural predators}

Biocontrol involves using natural predators to control rodent populations. The most common example is the use of barn owl (Tyto alba) boxes (fig. 11) to attract barn owl residence. Barn owls have long been lauded as an effective option for managing rodents such as pocket gophers, voles, and mice. One of the beneficial attributes of barn owls is that they are not overly territorial, which allows growers to artificially inflate barn owl numbers in a given area by erecting more homes (that is, barn owl boxes) for barn owls to use. Barn owls also consume large numbers of rodents each year-the number per owl is estimated at close to 3,000 rodents annually in California vineyards (Kross and Baldwin 2016) - indicating that they are effective predators of rodents. However, it is important to remember that barn owls will not necessarily be effective at reducing rodent

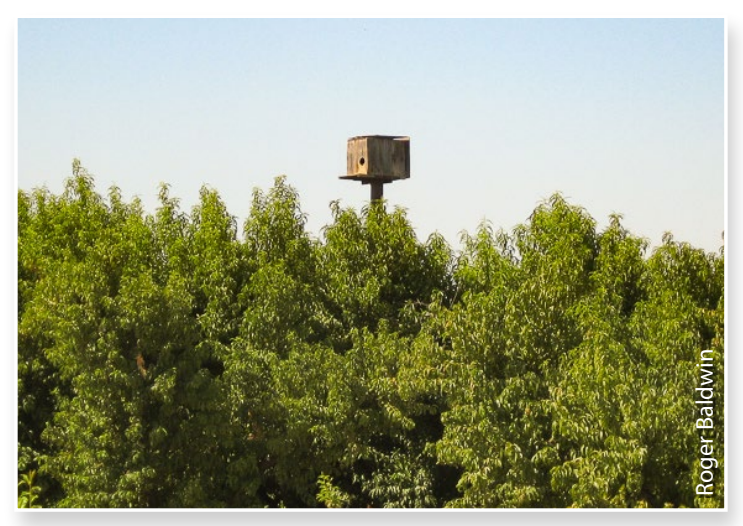

Figure 11. Barn owl box. 
densities just because they eat large numbers of rodents. For example, there is no way to know if barn owls are consuming rodents from the target fields or if instead they are feeding at alternative sites. Likewise, rodents reproduce at a very high rate, allowing them to replace lost numbers quickly. It also bears noting that when competing rodents are removed via predation, their removal increases resources for remaining rodents, thereby increasing the likelihood of their survival, as well as the number of young they are likely to produce. Currently, little available research indicates that barn owls are effective as a biocontrol agent in the United States. On the other hand, we do not know that they are ineffective either. At this time, there is no harm in using barn owl boxes as a means of reducing rodent numbers; however, we do not know what level of benefit to expect. For organic producers, though, there are few good alternatives, so barn owls' inclusion in an IPM program is likely warranted. Bear in mind that unoccupied owl boxes can be colonized by secondary pests such as Africanized honey bees, starlings, and others. Additional details on the use of barn owl boxes, including instructions on proper construction and placement, can be found in Ingels and Hoffman (2008) as well as in many free online sources, including publications by Audubon California.

It bears noting that barn owls are not effective predators of ground squirrels because their respective periods of activity do not overlap (barn owls are active at night and ground squirrels are active during the day). Raptor perches have instead been promoted for ground squirrel control. However, there is little evidence to suggest that this approach is especially effective. Likewise, gopher snakes (Pituophis catenifer; fig. 12) are unlikely to significantly control populations because of their low feeding rate-they consume perhaps as little as 1.5 times their body mass annually (Diller and Johnson 1988). This is not to say that natural predators are not an important part of the agricultural landscape. They are, and should be promoted to the extent tolerable to the landowner. They will remove offending rodents during the course of their hunting activities. However, in many or most cases-with the potential exception of barn owls supported by

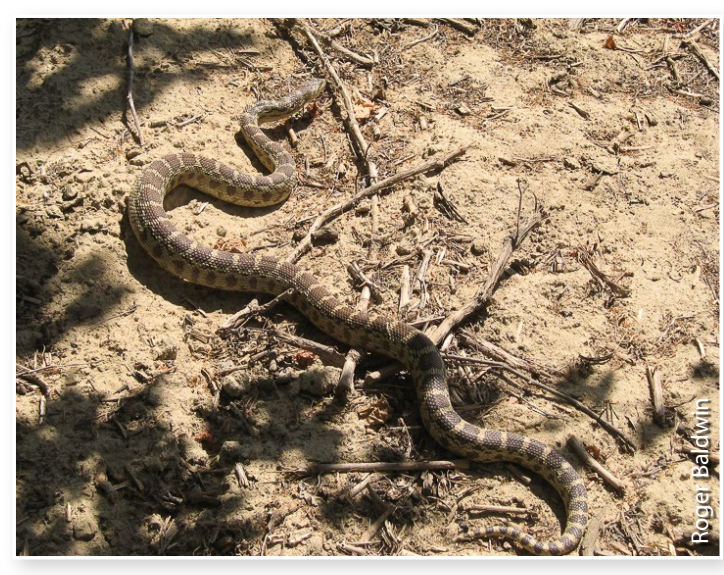

Figure 12. Gopher snake.

barn owl boxes-they will not be able to reduce rodent populations to a level acceptable to many growers. Consider predators a valuable part of an IPM program, but do not rely on them exclusively to manage your rodent problems. Regardless of the role played by raptors, snakes, and owls in a rodent IPM strategy, encouraging and supporting them can benefit the agricultural landscape and wildlife populations in other ways.

\section{Habitat modification through removing ground cover and controlling weeds}

Habitat modification is an important component of most IPM programs. Habitat modification is the process of altering the desirability of a given area for a particular pest species. This approach has varying levels of effectiveness for differing rodent species, but may be most effective against voles. Voles are very dependent on cover; without cover they are particularly susceptible to natural predation. Therefore, removing or reducing cover from fields is a great way to substantially reduce vole damage. Cover removal and reduction can be implemented in many ways. For example, if dealing with tree or vine crops, be sure to keep 2 to 3 feet of bare soil around the base of trees or vines and keep rows between trees and vines mowed low-preferably, less than 2 inches in stubble height (fig. 13). Litter produced by mowing, however, can form a thatch layer that can serve as good cover for voles. Be sure to keep this thatch layer away from the trunks of plants (Whisson and Giusti 1998). Mowing more frequently will minimize this thatch layer, ultimately helping to ease problems with voles. 


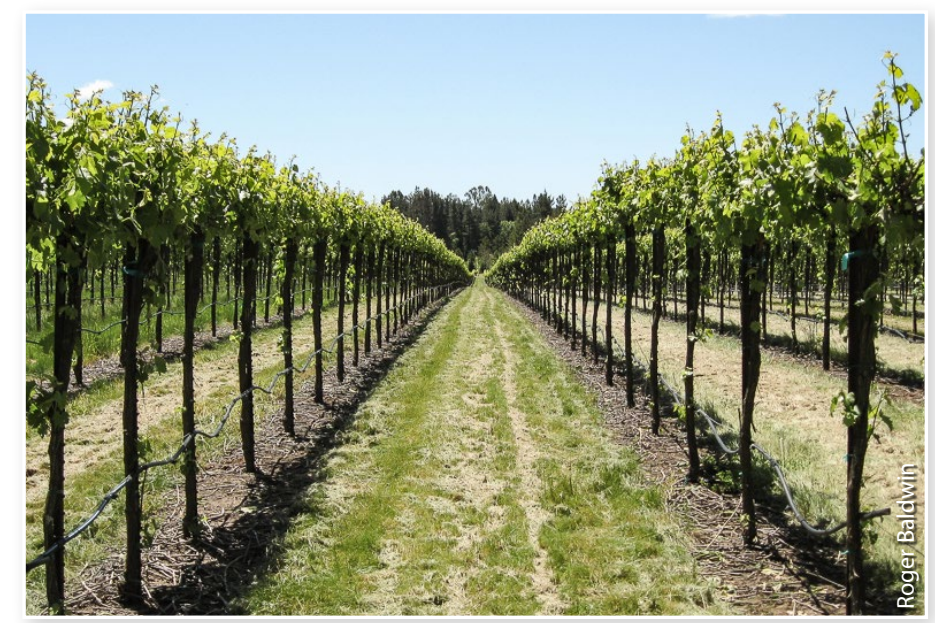

Figure 13. Mowing rows and leaving bare soil around the base of vines reduce likelihood of vole damage.

Very often, plastic mulch is used in organic production systems to suppress weed growth. These weed barriers provide ideal cover for voles, often leading to substantial problems associated with vole girdling of the stems of trees and vines. Removing the weed barrier, if possible, eliminates this problem.

Ground squirrels readily use brush and pruning piles as harborage sites within orchards and vineyards (fig. 14). Removing piles-both from production fields and the outside perimeters of fields, and preferably removing piles situated within 100 yards of fields - can help reduce damage associated with ground squirrels.

Cover crops are frequently planted within orchards and vineyards for a multitude of beneficial reasons. Unfortunately, these cover

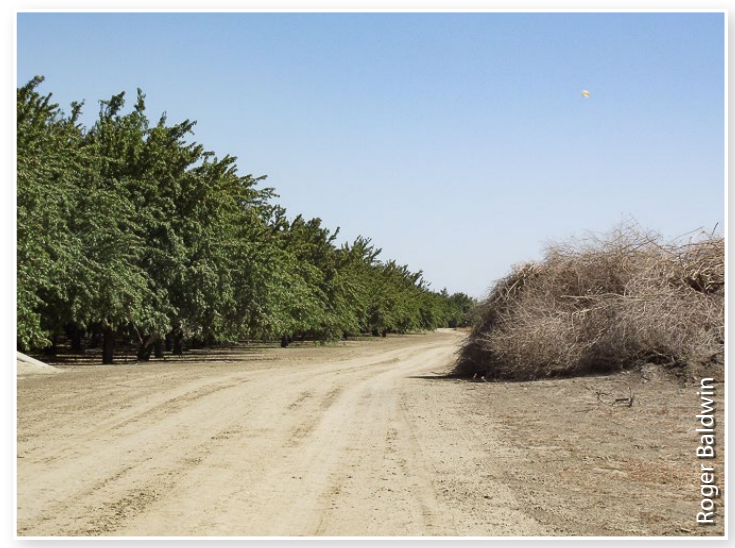

Figure 14. Removing brush piles can reduce habitat for ground squirrels. crops often provide food and cover resources that burrowing rodents need. Avoiding cover crops that contain legumes and associated nitrogen-fixing plants, as well as broadleaf plants with fleshy tap roots, is a good strategy for reducing numbers of most burrowing rodents. For voles, planting bunch grasses is a good strategy to reduce preferred cover as well (Whisson and Giusti 1998). For pocket gophers, the selection of lower-growing plants is preferred, as taller plants hide gopher signs, making identification of gopher infestations very challenging.

In both annual and perennial systems, incorporation of cover crops-for example, by disking - is one of the best approaches for reducing rodent damage. However, when deciding on the timing of cover crop termination, one must take into account the status of neighboring fields-a newly planted field is very vulnerable to rodent damage and may become the next food source for displaced rodents. Before cover crops are disked, it is important to first manage rodents in those fields. Eliminating cover and food resources before removing the rodents could-because rodents would lack alternative food sourceslead to a short-term increase in damage to the crop.

Planting native California flowering plants (hedgerows) as habitat on field borders is becoming more common as a means to attract natural enemies for pest control, and native bees for pollination services, in adjacent crops. Although some have expressed concern that hedgerow plantings can harbor rodents and lead to food safety problems, studies have shown that field-edge habitat is too narrow on a landscape scale to serve as habitat for large numbers of rodents (Sellers et al. 2018). Rodents are everywhere in our agricultural lands; they need to be monitored and managed regardless of field-edge habitat type. Rodents naturally disperse, colonizing new areas that contain suitable cover, such as within newly planted field and row crops like tomato and alfalfa. When these fields are disked for new plantings, the rodents living there disperse into neighboring fields, seeking new places to live. Keep an eye out for rodent damage in all crops, 
but especially in newly planted orchard and vineyard crops, which are most susceptible to girdling and subsequent tree and vine losses.

\section{Cultural practices}

Two cultural practices that help reduce rodents are flooding fields and destroying or deep-ripping burrow systems with tractor implements. With the water shortages frequently experienced in California, flood irrigation has become less common. Because flood irrigation can be a good tool for reducing rodent pressure within crop fields (Marsh 1992, 1998; Bertolino et al. 2015), some believe that reduced flooding has led to increased problems with burrowing rodents. If flood irrigation is still an option, consider periodically using it as a tool to help reduce problems with ground squirrels, gophers, and voles.

Deep-ripping of old ground squirrel burrow systems has been shown to substantially reduce reinvasion by adjacent populations of ground squirrels when fields are ripped to a depth of at least 18 inches (fig. 15). Shallower ripping efforts have proven to be ineffective, so establishing this minimal depth for ripping is key (Gilson and Salmon 1990). Burrow destruction should occur after ground squirrels have been removed from the site because burrow destruction in areas with extant ground squirrel populations has been ineffective (Gilson and Salmon 1990). Admittedly, burrow destruction is not possible in perennial crop production systems while the crops are in place. However, this approach can be effectively used before

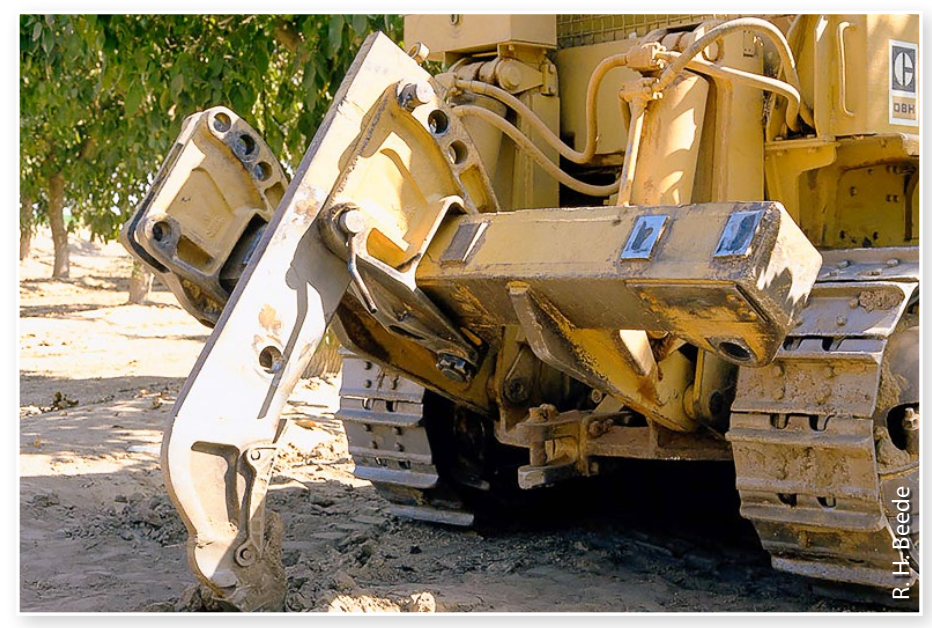

Figure 15. Deep-ripping implements can be used to destroy old burrow systems. replanting a field and on the perimeters of fields from which rodents often invade-so burrow destruction can be a valuable part of a long-term IPM program.

Burrow destruction has not been tested as a management tool for pocket gophers, but it is believed to be beneficial for this species as well. For gophers, a best "guess" is that ripping efforts will need to extend for 12 inches in depth to ensure destruction of most burrow systems (Marsh and Steele 1992).

In contrast to ground squirrels, burrow destruction for voles can be effective against extant vole populations (Jacob 2003; Baldwin et al. 2019). The depth of plowing and disking tested in studies was about 18 to 20 inches, but burrow destruction as shallow as 6 to 10 inches may be effective because of the shallower nature of vole burrow systems. The efficacy of burrow destruction at shallower depths, however, has not been tested. Frequency of tillage is generally dictated by replanting efforts, although disking of row middles in perennial orchard and vine crops, where possible, might provide some relief (see the section on habitat modification, above, for additional details).

Although no-till and reduced-tillage farming practices have obvious benefits for soil and water conservation purposes, it should be noted that these practices often exacerbate damage associated with burrowing rodents (Witmer et al. 2007). Fields should be continuually monitored for rodent activity, and removal efforts should be employed when needed, to alleviate problems with these species. No-till and reduced-tillage farming practices may not be very practical in areas with consistent rodent pressure (for example, sites located next to natural habitats such as riparian zones and grasslands).

\section{Exclusion through physical barriers}

Exclusion using fences, root baskets, and tree protectors can be an effective tool to reduce damage caused by pocket gophers and voles; however, the cost and effort involved vary, making some options more realistic than others.

Exclusionary fencing is not generally effective or practical for ground squirrels because 
of their digging and climbing capabilities. For gophers, buried perimeter fencing around fields has been suggested as a potential option for reducing damage, but field testing has not shown this approach to be effective (Salmon et al. 1990). Wire baskets placed around the root systems of newly planted trees may provide some relief, but they are expensive and likely impractical over large acreage. Raised beds with wire bottoms are also effective at reducing gopher damage in backyard gardens, but are difficult to translate to production systems. Exclusionary fencing for pocket gophers is generally not an option for large organic production systems.

When properly placed and operated, aluminum fencing can be effective at deterring vole movement into fields. Fencing should be buried at least 6 inches below ground and extend 10 to 12 inches above ground (fig. 16). Vegetation should be removed from around the base of the fence to keep voles from lingering around the exclusionary structure. If vegetation remains, the voles will have time to figure out a way around the fence, but if the vegetation is removed, they will be too susceptible to predation to linger. For aluminum fencing to be effective, as much as possible of the perimeter around the field must be fenced-otherwise, voles will simply travel down the fence line until they find a way in. Therefore, fencing can be an impediment to easy access by farm equipment into and out of a field. It is generally most practical when fields are next to other cover types (for example, natural areas, alfalfa fields, and vegetable crops) from which

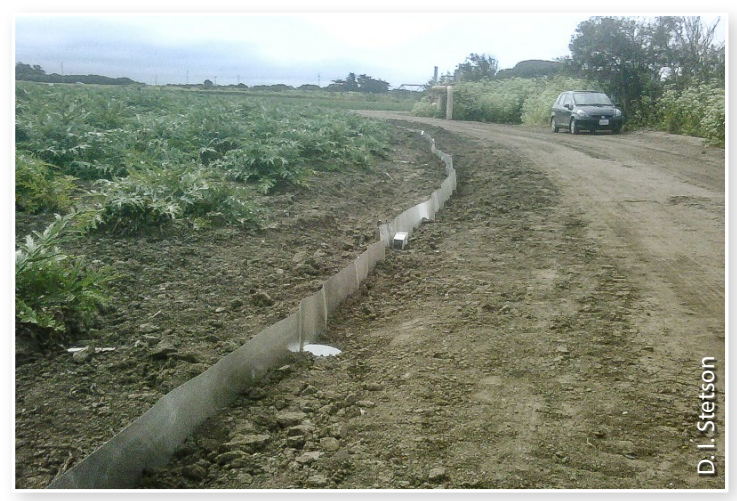

Figure 16. Aluminum fence to slow movement of voles into agricultural fields. frequent movement of voles into the organic fields is expected. This type of exclusionary approach will not eliminate problems with voles, but will help to slow movement into and out of fields. Likewise, this approach could be used in combination with traps or rodenticide bait stations that could intercept voles during dispersal events-but keep in mind that rodenticide use is not allowed within certified organic fields.

Vole damage to tree crowns can be overcome with plastic tree protectors (fig. 17). Tree protectors can also help protect against sunburn in young trees and mechanical damage from weeding near tree trunks. Tree protectors should be buried 2 to 6 inches below ground to reduce vole access (Davies and Pepper 1989; Marsh et al. 1990). If the protector is not buried, growers can actually see an increase in damage as the protectors will shelter the rodents from predators while they feed on the tree cambium.

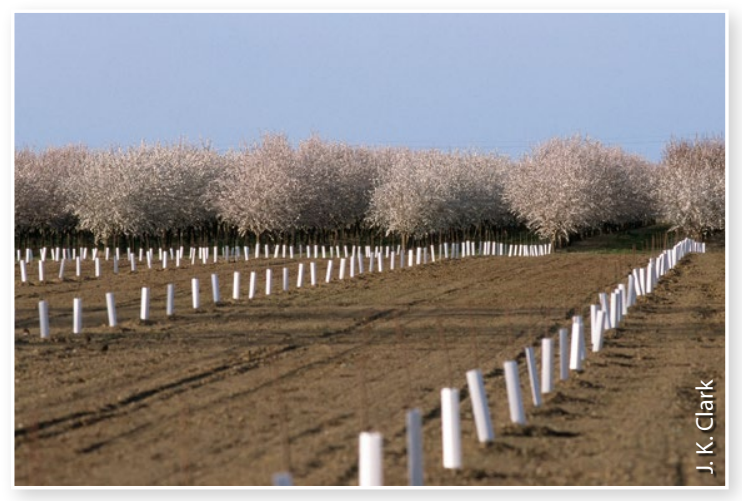

Figure 17. Plastic tree protectors are physical barriers that protect trees and vines from voles.

\section{Trapping}

Once rodents have become established in a given field, trapping becomes one of the few tools available to remove them. Trapping has variable applicability for burrowing rodents; it is highly efficacious and fairly cost-effective for pocket gophers (Baldwin et al. 2016), is moderately efficacious for ground squirrels (Marsh 1994; O'Connell 1994), and is a viable option for voles only when numbers are low (Witmer et al. 2009). A threshold for the number of burrowing rodents that cause economic damage has not been set and therefore depends on growers' observations. 


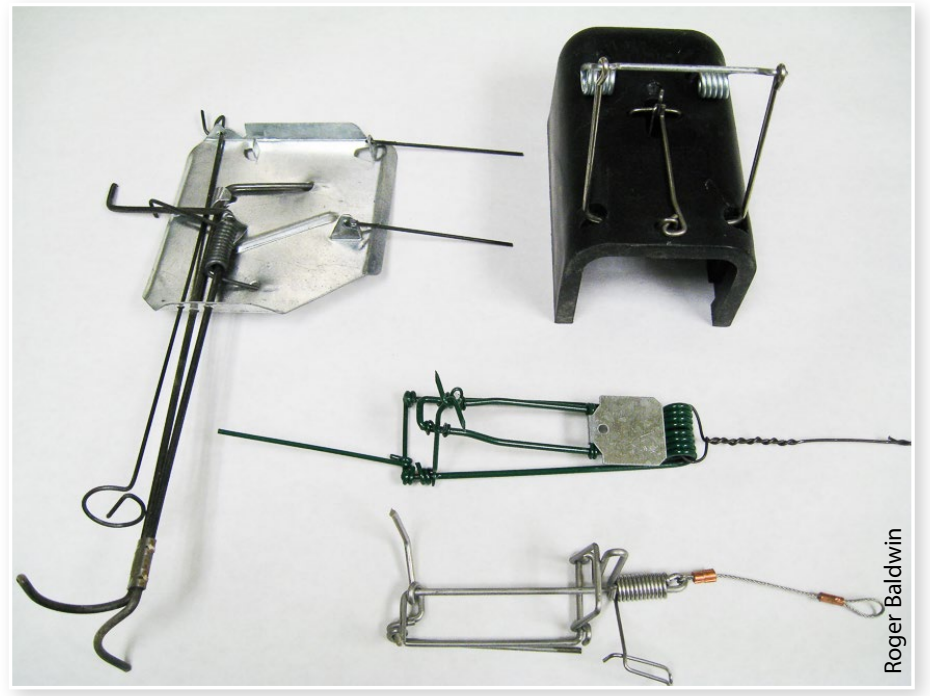

Figure 18. Common examples of gopher traps include the Cinch trap, Victor Black Box, Macabee, and Gophinator (shown clockwise from top left). Many other trap designs are available.

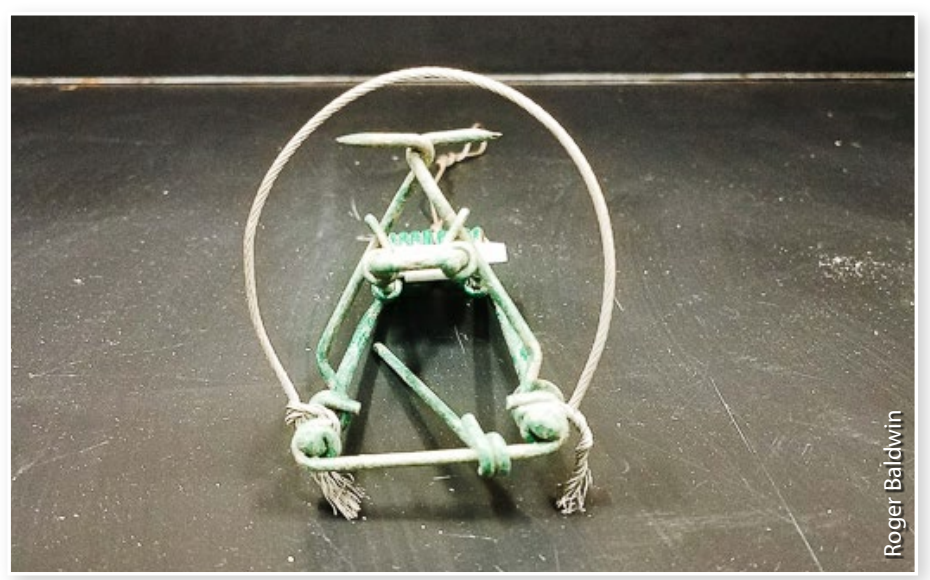

Figure 19. Modified Macabee designed to increase capture success for larger pocket gophers.

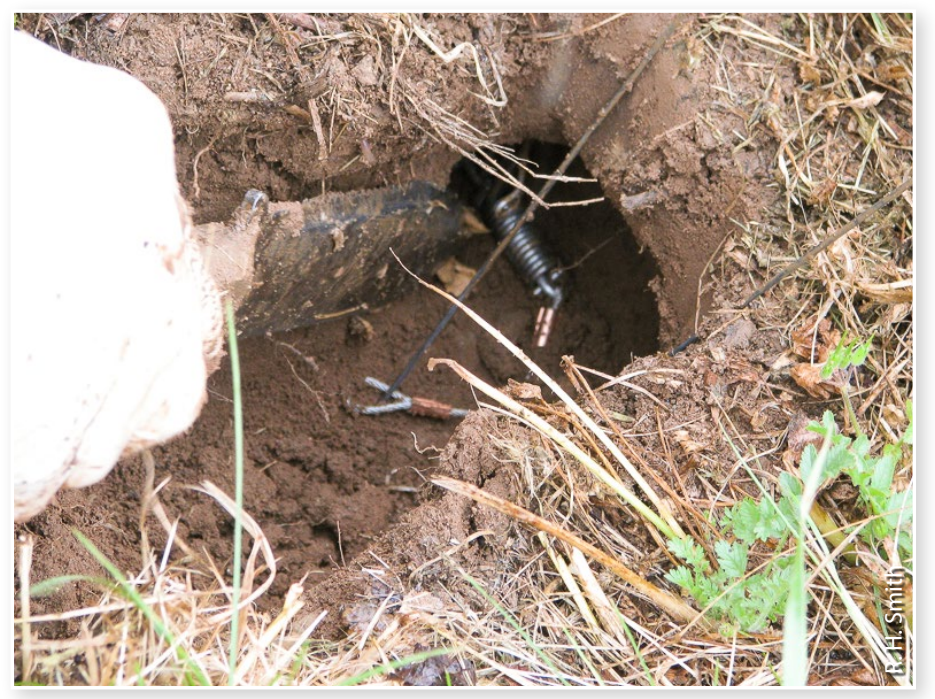

Figure 20. Example of gopher trap set.

\section{Pocket gophers}

Numerous trap designs are available for gophers, but they all basically fall into two categories: 1) pincer-style traps and 2) choker-style traps (fig. 18). Common pincer-style traps include the Macabee (and associated replicas), the Gophinator, the Cinch trap, and the Victor Easyset. Examples of choker-style traps include the Victor Black Box, the Blackhole trap, and the GopherHawk. Of trap types tested, the Gophinator trap (Trapline Products, Menlo Park, California) appears to be one of the most effective. In particular, it has proven more effective than the Macabee trap (Macabee Gopher Trap Co., Los Gatos, California), which is likely the most commonly used pocket gopher trap in California (Baldwin et al. 2013). The increased effectiveness of the Gophinator is due to its ability to capture larger individuals at a higher rate. In fact, for each 45-gram increase in size, Macabee traps were an additional 25 to 26 percent less effective than Gophinator traps (Baldwin et al. 2013). If an individual has old stockpiles of Macabee traps, their effectiveness can be increased by placing a cable restraint ( 0.06 inches in diameter and 9 inches in length) at the front of the Macabee trap to help keep larger individuals from escaping (fig. 19). However, the Gophinator trap is still more effective (Baldwin et al. 2015).

For trap placement, the first step is to probe near a fresh mound to find the main tunnel, which often is on the side closest to the plug of the mound. The main tunnel usually is 6 to 8 inches deep; the probe will drop quickly about 2 inches when the tunnel is encountered.

Because it isn't possible to know which side the pocket gopher is currently using, traps need to be placed in as many tunnels as are present (fig. 20). After you place the traps, you can cover the hole to keep light out of the tunnel. However, covering trap sets only marginally increases capture efficiency when temperatures are high (perhaps greater than $85^{\circ} \mathrm{F}$, although the exact impact of temperature is not known) and provides no increase in capture success at other times (Baldwin et al. 2013). Therefore, when a large number of traps are set, leaving the trap holes uncovered can save a substantial amount of time in setting and checking traps. 
Various attractants have been tested to determine if they increase capture success. In general, they do not appear to do so-though, if covered trap sets are used, using peanut butter as an attractant could produce a slight increase in capture success (Baldwin et al. 2014). Human scent also does not appear to influence capture success, so there is little reason to worry about handling traps with bare hands (Baldwin et al. 2015). Trap sets are typically operated for 24 hours. If no activity occurs in that time frame, the traps should be moved to a new location to maximize the probability of capture.

Pincer-type traps can also be placed in lateral tunnels, which are tunnels that lead directly to the surface. To trap in laterals, remove the plug from a fresh mound and place the trap in the lateral tunnel so that the entire trap is inside the tunnel. Pocket gophers will come to the surface to investigate the tunnel opening and will be caught. This approach is quicker and easier to implement than trapping in the main tunnel. However, trapping in lateral tunnels may be less effective at certain times of the year (for example, summer) and for more experienced pocket gophers (for example, adult males).

\section{Ground squirrels}

Trapping for ground squirrels can be an effective approach to reduce numbers in a given area. Trapping for ground squirrels can be effective year-round as long as the squirrels are active at the time the traps are in use (see fig. 10). Various types of traps are available, but all fall into two categories: 1) kill traps and 2) live traps. Kill traps kill the animal upon capture. Examples include body-gripping traps such as the Conibear 110, tube traps, and box-type squeeze traps. Because these traps kill captured animals, care must be taken when using the traps; they can kill nontarget animals (for example, cats, dogs, foxes, and kangaroo rats) just as they do target rodents.

In areas where nontarget captures are a concern-for example, where pets are present-live traps may be preferred. These are generally cage-style traps that house the animal unharmed. If a nontarget animal is captured, it can be released unharmed (Van Vuren et al. 1997). Examples of live traps include single-capture cage traps such as Tomahawk- or Havahart-style traps (fig. 21), as well as multiple-capture traps that allow multiple squirrels to be captured at once (for example, the Squirrelinator and the Black Fox repeating live trap). It is important to note that when using live traps, there are two options available upon capture. The first option is to let the squirrel go at the site of capture, which runs counter to the goal of removing ground squirrels from the property. The second option is to euthanize the ground squirrel on site after capture. Be aware that translocation, which is the transportation of wild animals out of their home ranges, is not legal or advisable in California for a variety of reasons. These include the potential establishment of problem animals in new areas and the potential to inadvertently spread wildlife diseases and parasites that otherwise might not have spread.

Squirrels should be euthanized in a humane manner. Two practical techniques are currently considered humane by the American Veterinary Medical Association. The first is shooting. This is a good solution if you are in an area where you can discharge a firearm (be aware that lead ammunition is no longer allowed in California; see the section on shooting, below,

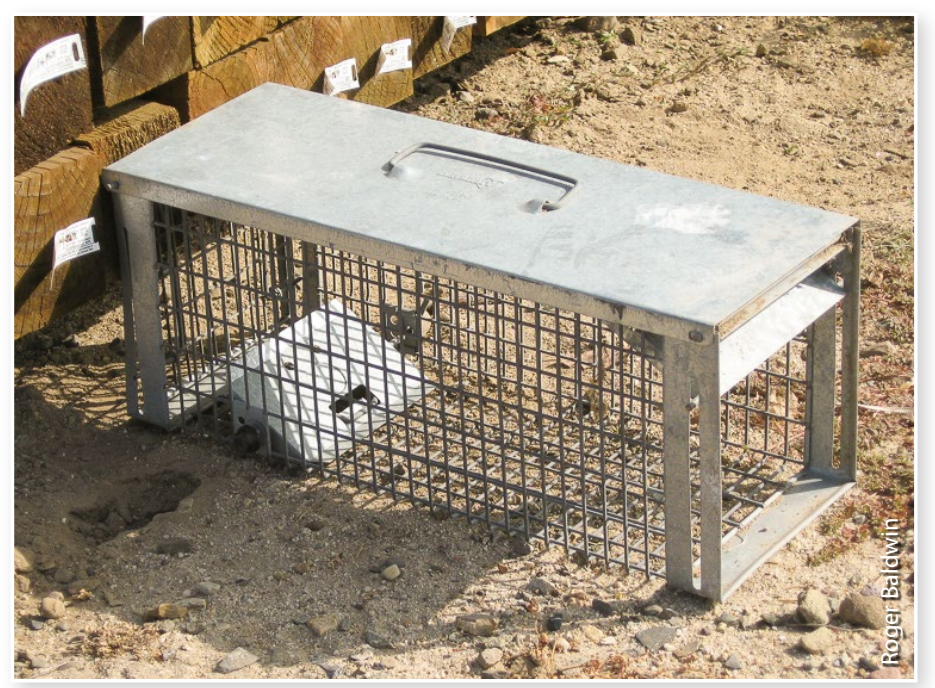

Figure 21. Example of a cage live trap frequently used to trap ground squirrels. 
for additional details). The second method is to utilize a carbon dioxide euthanasia chamber. This approach requires placing the trap, with a squirrel inside it, into the chamber, and then pumping carbon dioxide into the chamber until the animal passes out and eventually succumbs to the gas. This is an easy, humane, and relatively inexpensive method for euthanizing ground squirrels. Additional details on this process can be found at the Ground Squirrel Best Management Practices website, groundsquirrelbmp.com/euthanasia. $\mathrm{html}$. Drowning is no longer considered a humane form of euthanasia and, perhaps more importantly, is illegal for dispatching animals in California. One of the most important issues to understand regarding live trapping is that you need to know ahead of time how you will dispatch an animal after capture. Do not wait until after the animal is captured to figure out your euthanasia process.

Because trapping for ground squirrels can be challenging, it is best when possible to plan trapping efforts for early in the year, before young emerge above ground (Marsh 1994). Body-gripping traps such as the Conibear 110 are ideal for this use. These traps are set in the burrow entrance (fig. 22). They work best when the trap is flush to the surface of the soil, so a bit of excavation may be needed to accomplish this goal. Some trappers note greater success when offsetting the trigger mechanism to

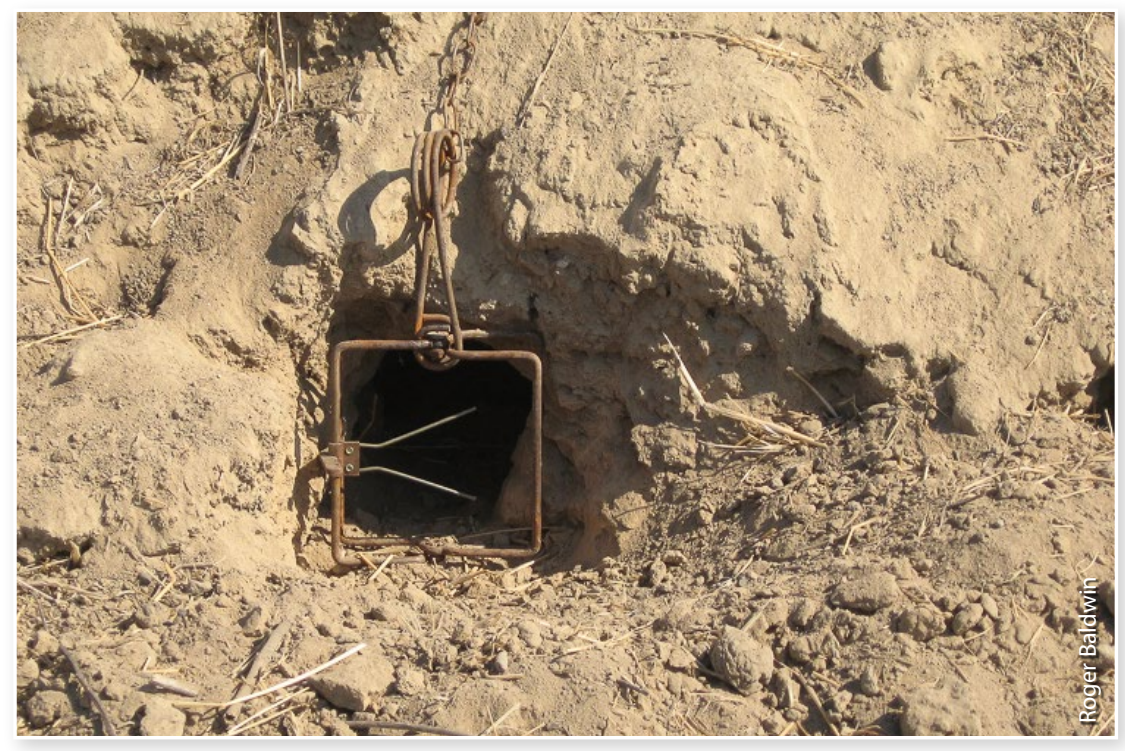

Figure 22. Body-gripping trap placed at a ground squirrel burrow entrance. the side somewhat to provide a less obscured view of the tunnel. One strategy for increasing the efficacy of this approach is to first plug up burrow entrances with soil, then come back the following day and set traps in entrances that have been reopened (Marsh 1994). One advantage of this style of trapping is that the trapper does not need to use bait to draw the ground squirrel into the trap. This is especially useful early in the year, when ground squirrels actively feed on new plant growth, making baits less attractive and less effective.

For all other ground squirrel traps (cage, tunnel, and box traps), baiting is necessary. These traps should be placed along ground squirrel runways or a few feet away from burrow entrances. Various baits can be used. Rolled oats are one of the simplest to use, but sometimes fresh fruit (for example, melons and apples), vegetables (for example, carrots and cabbage), and nuts work as well or better. Proper bait selection at a given site often relies on trial and error. Remember that the bait needs to be more desirable to squirrels than what they are already consuming; otherwise, they have no incentive to enter the trap.

Ground squirrels are often neophobic-they are afraid of new things. It can take them a few days to build up the courage to enter a trap. One strategy to overcome this fear is to prebait traps (Marsh 1994; O’Connell 1994). Prebaiting is the process of applying bait to traps without initially triggering the traps. This gets the ground squirrels accustomed to feeding on the bait and ultimately entering the traps. Once you notice that the bait is regularly removed from the traps, it is time to activate the traps. By minimizing opportunities for ground squirrels to see other individuals captured in traps, this approach reduces the impact of a learned avoidance response and therefore can increase capture success on a given day. Regardless of the type of trap, it is a good idea to stake all traps down to keep scavenging animals from running off with them.

California ground squirrels are considered a nongame species in California. Therefore, you do not need a license to trap ground squirrels unless you do so for hire. However, according 
to the California Fish and Game Code, traps do need to be checked on a daily basis.

\section{Voles}

Generally, trapping is only used for voles when a small number of voles need to be removed from a localized area. Otherwise, achieving effective reductions in vole populations requires too much effort. Within targeted areas, look for vole burrows and runways in grass or mulch. When trapping, place standard mouse-size snap traps along runways where voles regularly travel. The traps are set perpendicular to the runway so that the trigger mechanism of the activated trap bisects the runway (Witmer et al. 2009) (fig. 23). Voles do not regularly deviate from their runways; the vole will run right over the trigger mechanism, allowing for easy capture. In fact, bait is generally not used with these traps sets; not only is it not needed, but using unbaited traps reduces the likelihood of nontarget capture (often songbirds). Snap traps often have a nail (usually 2.5 to 3 inches in length) staked through them, into the ground, to keep the trap from flipping up upon triggering. Traps should be examined daily. Dead voles should be removed, and sprung traps should be reset, as needed. Continue to trap in one location until you stop catching voles, then move the traps to a new location 15 to 20 feet away. One hundred traps or more will likely be required when trapping even a relatively small area (Salmon and

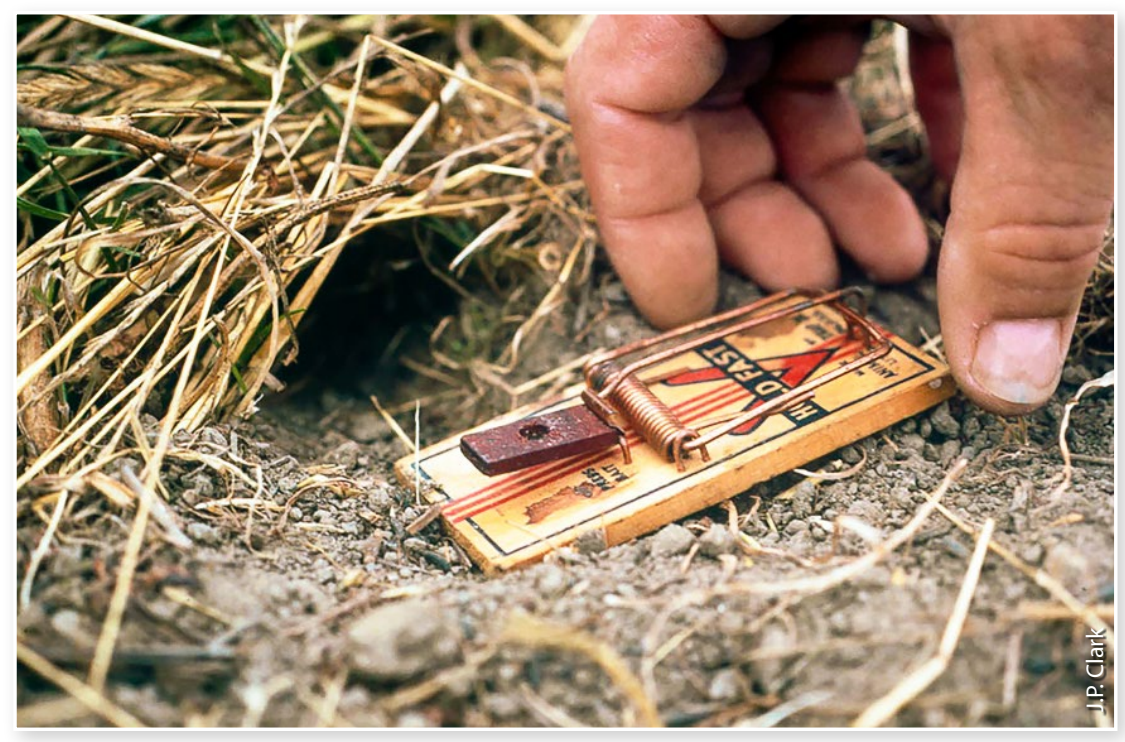

Figure 23. Snap trap placed perpendicular to a vole runway.
Gorenzel 2010), so make sure that you have sufficient supplies on hand to engage in a vole trapping program.

\section{Shooting}

Shooting can be effective at controlling ground squirrels if the effort is consistent, but it is labor-intensive. But with few alternative options available, shooting can be an important part of an IPM program for ground squirrels in organic production systems. As mentioned previously, be advised that lead ammunition is no longer permitted for vertebrate control in the state of California. Lead alternatives can be more costly and more challenging to find for some firearms, somewhat limiting the utility of this approach. Be sure to understand and adhere to all federal, state, and local ordinances for discharging a firearm.

\section{DEVELOPING AN IPM PROGRAM}

The best IPM programs constantly adapt to changing situations in a given field-and continual thought and evaluation are required to identify effective strategies for rodent management, especially in organic production systems with limited highly efficacious options. For example, when managing pocket gophers in a tree crop, you need to consider the stage of the orchard. If the orchard is older, trees can likely sustain some level of girdling or root consumption without too much effect on production. In such cases, general maintenance of gopher populations may be all that is needed (for example, occasional trapping efforts, weed control to reduce preferred foods, and use of barn owl boxes to remove some gophers).

Conversely, if an orchard is set for replanting, more attention to gopher control may be justified. One approach is first to remove most or all gophers through a trapping program shortly before replanting is to begin. Deep ripping could then be implemented to destroy all old burrow systems. This would provide a "clean slate," allowing an effective long-term management program to be implemented. Low populations of gophers can be managed through biocontrol efforts such as installing owl boxes or raptor perches. Following initial planting of new trees, a regular monitoring 
and trapping program could be implemented, with gophers removed as soon as new mounds appear. If gophers and gopher tunnels were removed from the entire orchard before planting, new activity will mostly occur along the orchard perimeter, greatly reducing the amount of monitoring effort required within the orchard. As long as gophers are not allowed to establish themselves within the orchard interior, this monitoring process will remain relatively easy. Proper vegetation management is needed to allow for easy identification of new mounds when they appear. This cycle can be repeated throughout the life span of the orchard, minimizing concern over gophers. Of course, this is but one example of a potential IPM program. Many other management programs could be developed for gophers and other burrowing rodents. In organic production systems, effective rodent management will rely heavily on ensuring that rodent populations do not build up to numbers that are too high to effectively manage with available tools. Implementation of multiple strategies, most notably habitat modification and cultural practices, will frequently be the cornerstone of effective rodent management programs in organic fields.

\section{RESOURCES}

Ground Squirrel BMP Website, groundsquirrelbmp.com

Vertebrate Pest Control Handbook, vpcrac.org/ about/vertebrate-pest-handbook/

UC Integrated Pest Management Pest Note: Ground Squirrel, ipm.ucanr.edu/PMG/PESTNOTES/pn7438.html

UC Integrated Pest Management Pest Note: Pocket Gophers, ipm.ucanr.edu/PMG/PESTNOTES/pn7433.html

UC Integrated Pest Management Pest Note: Voles (Meadow Mice), ipm.ucanr.edu/PMG/ PESTNOTES/pn7439.html

\section{REFERENCES}

Baldwin, R. A., A. Chapman, C. P. Kofron, R. Meinerz, S. B. Orloff, and N. Quinn. 2015. Refinement of a trapping method increases utility for pocket gopher management. Crop Protection 77:176-180. https://doi. org/10.1016/j.cropro.2015.08.003

Baldwin, R. A., D. B. Marcum, S. B. Orloff, S. J. Vasquez, C. A. Wilen, and R. M. Engeman. 2013. The influence of trap type and cover status on capture rates of pocket gophers in California. Crop Protection 46:7-12. https:// doi.org/10.1016/j.cropro.2012.12.018

Baldwin, R. A., R. Meinerz, and S. B. Orloff. 2014. The impact of attractants on pocket gopher trapping. Current Zoology 60(4):472-478. https://doi.org/10.1093/ CZOOLO/60.4.472

Baldwin, R. A., R. Meinerz, and S. B. Orloff. 2016. Burrow fumigation versus trapping for pocket gopher (Thomomys spp.) management: a comparison of efficacy and cost effectiveness. Wildlife Research 43(5):389397. https://doi.org/10.1071/WR16037

Baldwin, R. A., D. I. Stetson, M. G. Lopez, and R. M. Engeman. 2019. An assessment of vegetation management practices and burrow fumigation with aluminum phosphide as tools for managing voles within perennial crop fields in California, USA. Environmental Science and Pollution Research 26:1843418439. https://doi.org/10.1007/s11356-01905235-6

Bertolino, S., L. Asteggiano, M. A. Saladini, L. Giordani, G. Vittone, and A. Alma. 2015. Environmental factors and agronomic practices associated with Savi's pine vole abundance in Italian apple orchards. Journal of Pest Science 88:135-142. https://doi. org/10.1007/s10340-014-0581-7

Cox, G. W., and J. Hunt. 1992. Relation of seasonal activity patterns of valley pocket gophers to temperature, rainfall, and food availability. Journal of Mammalogy 73(1):123134. https://doi.org/10.2307/1381873

Davies, R. J., and H. W. Pepper. 1989. The influence of small plastic guards, treeshelters and weed control on damage to young broadleaved trees by field voles (Microtus agrestis). Journal of Environmental Management 28:117-125. https://agris.fao.org/ agris-search/search.do?recordID=GB8905997 
Diller, L. V., and D. R. Johnson. 1988. Food habits, consumption rates, and predation rates of western rattlesnakes and gopher snakes in southwestern Idaho. Herpetologica 44:228233. https://www.jstor.org/stable/3892521

Gilson, A., and T. P. Salmon. 1990. Ground squirrel burrow destruction: control implications. Proceedings of the Fourteenth Vertebrate Pest Conference 14:97-98. https:// digitalcommons.unl.edu/vpc14/33/

Ingels, C., and T. Hoffman. 2008. Barn owls and barn owl nest boxes. In: W. Tietje, ed., Songbird, bat and owl boxes: vineyard management with an eye toward wildlife. Oakland: UC Agriculture and Natural Resources Publication 21636. 27-36. https://anrcatalog.ucanr.edu/Details. aspx?item $\mathrm{No}=21636$

Marsh, R. E. 1992. Reflections on current (1992) pocket gopher control in California. Proceedings of the Vertebrate Pest Conference 15:289-295. https://escholarship.org/uc/ item/2j76r0pb

Marsh, R. E. 1994. Current (1994) ground squirrel control practices in California. Proceedings of the Vertebrate Pest Conference 16:61-65. https://digitalcommons.unl.edu/ vpc16/35?utm_source=digitalcommons. unl.edu\%2Fvpc16\%2F35\&utm_ medium $=$ PDF\&utm campaign $=$ PDFCoverPages

Marsh, R. E. 1998. Historical review of ground squirrel crop damage in California. International Biodeterioration and Biodegradation 42(2-3):93-99. https://doi. org/10.1016/S0964-8305(98)00014-6

Marsh, R. E., A. E. Koehler, and T. P. Salmon. 1990. Exclusionary methods and materials to protect plants from pest mammals-a review. Proceedings of the Vertebrate Pest Conference 14:174-180. https://escholarship.org/uc/ item/9766f2h9

Marsh, R. E., and R. W. Steele. 1992. Pocket gophers. In H. C. Black, ed., Silvicultural approaches to animal damage management in Pacific Northwest forests. Portland: U.S. Forest Service, Pacific Northwest Research Station General Technical Report PNW-GTR -287. https://doi.org/10.2737/PNW-GTR-287

O’Connell, R. A. 1994. Trapping ground squirrels as a control method. Proceedings of the Vertebrate Pest Conference 16:66-67. https:// digitalcommons.unl.edu/cgi/viewcontent. cgi ?article $=1042 \&$ context $=$ vpc16
Quinn, N. M., M. J. Dimson, and R. A. Baldwin. 2018. UC IPM Pest Notes: Ground squirrel (revised). Oakland: UC Agriculture and Natural Resources Publication 7438. https:// ucanr.edu/sites/cetrinityucdavisedu/ files/303582.pdf

Salmon, T. P., and W. P. Gorenzel. 2010. UC IPM Pest Notes: Voles (meadow mice). Oakland: UC Agriculture and Natural Resources Publication 7439. http://ipm.ucanr.edu/PDF/ PESTNOTES/pnvoles.pdf

Salmon, T. P., R. H. Schmidt, and R. E. Marsh. 1990. An evaluation of fencing to exclude pocket gophers from experimental plots. Proceedings of the Vertebrate Pest Conference 14:95-96. https://digitalcommons.unl.edu/cgi/ viewcontent.cgi article $=1072 \&$ context $=$ vpc14

Sellers, L. A., R. F. Long, M. T. Jay-Russell, X. Li, E. R. Atwill, R. M. Engeman, and R. A. Baldwin. 2018. Impact of field-edge habitat on mammalian wildlife abundance, distribution, and vectored foodborne pathogens in adjacent crops. Crop Protection 108:1-11. https://doi. org/10.1016/j.cropro.2018.02.005

Van Vuren, D., A. J. Kuenzi, I. Loredo, and M. L. Morrison. 1997. Translocation as a nonlethal alternative for managing California ground squirrels. Journal of Wildlife Management 61 (2):351-359. https://doi.org/10.2307/3802591

Whisson, D. A., and G. A. Giusti. 1998. Vertebrate Pests. In C. A. Ingels, R. L. Bugg, G. T. McGourty, and L. P. Christensen, eds. Cover cropping in vineyards: a grower's handbook, 126-131. UC Agriculture and Natural Resources Publication 3338. https://anrcatalog.ucanr.edu/Details. aspx?item No=3338

Witmer, G., R. Sayler, D. Huggins, and J. Capelli. 2007. Ecology and management of rodents in no-till agriculture in Washington, USA. Integrative Zoology (2):154-164. https://doi. org/10.1111/j.1749-4877.2007.00058.x

Witmer, G., N. P. Snow, L. Humberg, and T. Salmon. 2009. Vole problems, management options, and research needs in the United States. Proceedings of the Wildlife Damage Management Conferences 13:235-249. https://digitalcommons.unl. edu/icwdm_wdmconfproc/140?utm_ source $=$ digitalcommons.unl. edu\%2Ficwdm_wdmconfproc\%2F140\&utm _ medium $=$ PDF\&utm campaign $=$ PDFCoverPages 


\section{FOR MORE INFORMATION}

To order or obtain UC ANR publications and other products, visit the UC ANR online catalog at https://anrcatalog.ucanr. edu/ or phone 1-800-994-8849. Direct inquiries to

UC Agriculture and Natural Resources

Publishing

2801 Second Street

Davis, CA 95618

Telephone 1-800-994-8849

E-mail: anrcatalog@ucanr.edu

(c)2021 The Regents of the University of California. This work is licensed under the Creative Commons AttributionNonCommercial-NoDerivatives 4.0 International License. To view a copy of this license, visit https://creativecommons.org/ licenses/by-nc-nd/4.0/ or send a letter to Creative Commons, PO Box 1866, Mountain View, CA 94042, USA.

Publication 8688

ISBN-13: 978-1-62711-163-8

The University of California, Division of Agriculture and Natural Resources (UC ANR) prohibits discrimination against or harassment of any person in any of its programs or activities on the basis of race, color, national origin, religion, sex, gender gender expression, gender identity, pregnancy (which includes pregnancy, childbirth, and medical conditions related to pregnancy or childbirth), physical or mental disability, medical condition (cancer-related or genetic characteristics), genetic information (including family medical history), ancestry, marital status, age, sexual orientation, citizenship, status as a protected veteran or service in the uniformed services (as defined by the Uniformed Services Employment and Reemployment Rights Act of 1994 [USERRA]), as well as state military and naval service.

UC ANR policy prohibits retaliation against any employee or person in any of its programs or activities for bringing a complaint of discrimination or harassment. UC ANR policy also prohibits retaliation against a person who assists someone with a complaint of discrimination or harassment, or participates in any manner in an investigation or resolution of a complaint of discrimination or harassment. Retaliation includes threats, intimidation, reprisals, and/or adverse actions related to any of its programs or activities.

UC ANR is an Equal Opportunity/Affirmative Action Employer. All qualified applicants will receive consideration for employment and/or participation in any of its programs or activities without regard to race, color, religion, sex, national origin, disability, age or protected veteran status.

University policy is intended to be consistent with the provisions of applicable State and Federal laws.

Inquiries regarding the University's equal employment opportunity policies may be directed to: Affirmative Action Compliance and Title IX Officer, University of California, Agriculture and Natural Resources, 2801 Second Street, Davis, CA 95618, (530) 750-1343. Email: titleixdiscrimination@ ucanr.edu. Website: https://ucanr.edu/sites/anrstaff/Diversity/ Affirmative_Action/

To simplify information, trade names of products have been used. No endorsement of named or illustrated products is intended, nor is criticism implied of similar products that are not mentioned or illustrated.

An electronic copy of this publication can be found at the UC ANR catalog website, https://anrcatalog.ucanr.edu/.

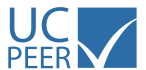

This publication has been anonymously peer reviewed for technical accuracy by University REVIEWED of California scientists and other qualified professionals. This review process was managed by UC ANR Associate Editor for vegetable crops and plant pathology Brenna J. Aegerter.

web-4/21-LC/SO 